\title{
Chapter 13 \\ Double Dividend of the Carbon Tax \\ in Japan: Can We Increase Public \\ Support for Carbon Pricing?
}

\author{
Kenji Asakawa, Kouichi Kimoto, Shiro Takeda, and Toshi H. Arimura
}

\begin{abstract}
Carbon pricing is difficult to introduce in many countries because it is not easy to obtain public support for carbon pricing due to the burden associated with it. One way to overcome this difficulty is to rely on the double dividend of a carbon tax. If a government uses revenue from a carbon tax to reduce existing distorting taxes, such as corporate taxes or labor taxes, a carbon tax can improve economic efficiency while reducing greenhouse gas $(\mathrm{GHG})$ emissions. This chapter examines the net burden of a carbon tax with revenue recycling (RR) for two types of stakeholders: firms and households. Using dynamic computable general equilibrium (CGE) modeling, we examine the carbon prices needed to achieve the emission targets set for 2030 and 2050. Then, we simulate two types of RR: corporate tax reduction and a reduction in social security payments. We compare the benefit of the tax reduction to the increase in the burden from the carbon tax in scenarios for 2030/2050. In the scenario of corporate tax reduction, by selecting firms from the land transportation sector and power sector, we examine how profit changes due to the carbon tax. We find that the tax burden for a firm in the land transportation sector can be eased greatly with the corporate tax reduction. In the scenario of the social security payment reduction, we find that some households are better off under carbon pricing despite expenditure
\end{abstract}

Toshi Arimura and Shiro Takeda appreciate financial support from the Foundation of Japanese Bankers' Association.

K. Asakawa

Institute for Global Environmental Strategies (IGES), Hayama, Japan

K. Kimoto · T. H. Arimura ( $\varangle)$

Faculty of Political Science and Economics, Waseda University, 1-6-1 Nishi-Waseda,

Shinjuku-ku, Tokyo 169-8050, Japan

e-mail: toshi.arimura@gmail.com

S. Takeda

Kyoto Sangyo University, Kyoto, Japan

K. Kimoto

Research Institute for Environmental Economics and Management, Waseda University, Tokyo, Japan

T. H. Arimura and S. Matsumoto (eds.), Carbon Pricing in Japan,

Economics, Law, and Institutions in Asia Pacific,

https://doi.org/10.1007/978-981-15-6964-7_13 
increases due to the carbon tax. Thus, we show that RR can increase support for the carbon tax.

\section{Introduction}

Carbon pricing is known as the most efficient way to reduce greenhouse gas (GHG) emissions in an economy. As shown in the previous chapters, carbon pricing at the regional level in Japan, namely, the Tokyo emissions trading system (ETS) (Chap. 6) and Saitama ETS (Chap. 7), has been successfully reducing GHG emissions. The national government, however, has not introduced an ETS. Moreover, the carbon tax introduced at the national level in 2012 was only 289 yen per ton of CO2 (Chap. 1), which is equivalent to 0.78 yen per liter of gasoline.

In Japan, the current level of the carbon tax is still not enough to achieve the long-term emission reduction goal set for 2050 (Chap. 1); thus, it is expected that the government will increase the tax rate (or introduce a nationwide emissions trading scheme) in the near future. However, when increasing the carbon tax, policymakers often face strong opposition from various stakeholders, who bear the burden of the direct price increase due to carbon pricing (Carattini et al. 2017). Overall, the opposition from the economic sector is most prominent. The economic cost, however, can be eased if the revenue from carbon pricing is used wisely. For example, if the revenue of the carbon tax is used to reduce the corporate tax, we can expect an expansion in investment because the net return of the investment increases as the corporate tax rate is reduced. This increase in investment will lead to an increase in production and hence an increase in the GDP. Alternatively, governments can use the revenue of the carbon tax to reduce the social security burden of employers. In this case, we can expect an increase in employment, which also leads to an increase in the GDP through an expansion in production activities. In this way, the revenue recycling $(\mathrm{RR})$ of the carbon tax can lead to economic growth.

This revenue recycling process is known as the "double dividend" of carbon pricing ${ }^{1}$. When the gains from RR offset the cost of the price increase due to carbon pricing, GDP or welfare can improve to a level better than that without carbon pricing. The introduction of carbon pricing with RR is also known as "environmental tax reform" because environmental tax (carbon tax) revenue is used to reduce the existing distorting tax. A carbon tax with RR can even increase the GDP or welfare if the strong double dividend holds.

Various studies have investigated the possibility of the double dividend. Saveyn et al. (2011) used a computable general equilibrium (CGE) model for the EU and investigated the impacts of carbon regulations on economies. They found a double dividend when permit revenues are used to reduce the social security contribution

\footnotetext{
${ }^{1}$ There are two types of double dividends. When the net gain is positive, it is referred to as the "strong double dividend". Otherwise, it is known as the "weak double-dividend". See Goulder (1995) for the details.
} 
of employees. Carbone et al. (2013) developed a dynamic CGE model for the US economy and found a double dividend when recycling revenues are used to reduce capital taxes (i.e., corporate taxes or personal income taxes on interest, dividends, or capital gains). Jorgenson et al. (2013) also examined the possibility of a double dividend by developing a CGE model for the US economy and found a double dividend when carbon tax revenues are used to reduce capital tax. Furthermore, Pereira et al. (2016) constructed a dynamic CGE model for Portugal and examined the carbon tax policy. They found a double dividend when carbon tax revenues are used for the policy, including the cut in social security contribution and personal income taxes. Thus, researchers validated the idea of the double dividend for several countries with economic models. One can refer to Freire-González (2017) for the literature of the double dividend

The idea of the double dividend has been adopted in the reforms of other countries. When Germany adopted energy tax reform in 1999, tax revenue was used to reduce statutory pension contributions (Beuermann and Santarius 2006). The United Kingdom adopted this idea as well (Agnolucci 2009). Recently, the province of British Columbia in Canada has adopted this idea. They used carbon tax revenue to reduce corporate taxes and successfully achieve economic growth and GHG emission reduction (Yamazaki 2017).

In the case of Japan, using a CGE model, Takeda (2007) shows the possibility of double dividends using RR for corporate taxes. Lee et al. (2015) also assesses the double dividend for the Japanese economy using a macroeconometric model. More recently, to achieve the long-term goal of emission reduction, Takeda and Arimura (2020) characterize the nature of the double dividend for the Japanese economy and confirm that corporate tax reduction using carbon tax revenue can lead to economic growth by 2030 . However, even if economic growth is achieved at the macro level, the tax burden varies among strong stakeholders. Some may win or some may lose.

To increase public support for the carbon tax with RR, it is useful to illustrate how the tax burden can be eased with RR. To address the concerns of industrial stakeholders, it is important for policy makers to show how much tax burden would be reduced for each sector. However, it is often the case that firms would not appreciate an analysis conducted at the sector level. Industrial stakeholders often want to see the results of an analysis at the firm level showing how their profit would be affected by the carbon tax with RR (IGES 2016). Thus, by selecting specific firms from two sectors, this chapter investigates how the profit would change under the carbon tax with RR in 2050.

Another important stakeholder that affects the public support of carbon pricing is households. The tax burden from carbon pricing can be eased with RR. There are several ways to improve the economic efficiency of household behavior through RR. One way to do so is to use carbon tax revenue to reduce social security payments. In this case, households have incentives to increase their labor supply. Moreover, under this scenario, households' payments to social security would decrease, and hence, households may be better off even with the increase in the carbon tax burden. We investigate whether this can be case for the Japanese economy while aiming for a long-term reduction in $\mathrm{CO}_{2}$. 
The analysis in this chapter is conducted in the following way. First, we conduct a CGE analysis of carbon pricing needed to reach the 2050 long-term reduction target. We calculate the carbon tax rate necessary to achieve the 2030 and 2050 targets. In this simulation, we make several assumptions. In the BAU scenario (where the carbon tax is not introduced), we adopted the current policies scenario in World Energy Outlook 2018 (IEA 2018), i.e., an average annual GDP growth rate of $0.7 \%$ and an average $\mathrm{CO}_{2}$ emission reduction rate of $0.6 \%$. By employing the CGE model, we can identify the output for each sector in 2050 and use the results for the simulation for corporate tax reduction. We also use the tax revenue obtained from CGE modeling to determine the size of a feasible corporate tax reduction. Regarding the social security payment reduction scenario, we use carbon pricing needed to achieve the 2030 target. Again, we use the CGE simulation results to calculate a social security payment reduction that is feasible with the carbon tax revenue. Furthermore, we use the results from the input-output analysis conducted by Kameoka \& Arimura (2019) to identify the increase in household expenditures. This chapter is organized as follows. Section 2 describes the CGE model used to calculate the macro outcome of the carbon tax to achieve the 2050 long-term goal. In Sect. 3, we analyze the impacts of the corporate tax reduction under the carbon tax on firms in selected sectors. Section 4 examines the impacts of the social security tax reduction under carbon tax reform on households. The final section concludes the chapter by discussing public support for carbon pricing.

\section{A Dynamic CGE Model for the 2050 Long-Term Target and the Results}

\subsection{A CGE Model}

We use a dynamic CGE model for the Japanese economy, which is constructed in Takeda and Arimura (2020), and analyze the impacts of environmental tax reform under a scenario that includes the long-term emission reduction target for the year 2050. Using the CGE model, we derive the quantitative impacts of environmental tax reform on aspects of the macroeconomy, such as the GDP, national income and tax revenue, including carbon tax revenue. In addition, we calculate the sectoral impacts such as the output and price of individual sectors. These results are used in later sections. In this section, we explain the simulation based on the CGE model. Because of space limitations, we provide only a brief summary of the analysis. The complete description of the analysis is presented in Takeda and Arimura (2020). For details, see this article.

Our model is a forward-looking dynamic general equilibrium model for the Japanese economy. To perform a CGE analysis, we need to construct a benchmark dataset. For this, we use 2011 input-output data on Japan (MIC 2016). To analyze $\mathrm{CO}_{2}$ regulations, we also need $\mathrm{CO}_{2}$ emissions data associated with the energy use 
of production sectors and households. For $\mathrm{CO}_{2}$ emissions data, we use the 3EID (Embodied Energy and Emission Intensity Data for Japan Using Input-Output Tables) dataset (Nansai et al. 2018). Our model is a general equilibrium model with 49 goods and 39 sectors including 14 energy goods and four electricity sectors. We aggregate the original input-output (IO) data for Japan and create the aggregated datasets. To analyze the role of energy goods in detail, we highly disaggregate the energy goods and sectors. Basically, one sector produces one good. However, some sectors, such as the petroleum goods sector and coal products sector, produce multiple energy goods. Moreover, some goods, such as electricity, are produced by multiple sectors. Thus, there is not always a one-to-one relation between goods and sectors.

All markets are perfectly competitive, and all agents behave as price takers. We assume that all producers have "constant returns to scale" technology, and producers maximize their profit by choosing the quantity of output and input (primary factors and intermediate inputs). We employ two types of production functions: the fossil fuel production function and the nonfossil fuel production function. Fossil fuel production activities include the extraction of coal, crude oil, and natural gas. However, nonfossil fuel production activities are used for all other sectors, including the electricity sector.

To represent the demand side of the economy, we use a representative household. The period utility (utility in a period) of the representative household depends on consumption and leisure. Because it is under a budget constraint, the household chooses values for consumption, leisure and saving (= investment) that will maximize lifetime utility, which is the sum of discounted period utility. Household income consists of primary factor income minus tax payments. In this model, the household labor supply is determined by the choice between leisure and labor supply. Thus, labor supply is an endogenous variable. The decreasing population of Japan is captured by the decreasing endowment of time that the representative household can use for leisure and work.

For CGE analyses on climate change policy, a recursive dynamic model is often used. In a recursive dynamic model, investment is determined by myopic agents and thus not affected by policy changes in the future (only affected by the past and current policy). In this analysis, we would like to analyze a scenario in which corporate tax is reduced. To capture the effects of a change in corporate tax, we use a forward-looking dynamic model used in the macroeconomic literature. In a forward-looking model, investment is determined by the dynamic optimization behavior of the household, and the capital stock owned by the household accumulates gradually through investment.

Our model covers a long time span (from 2011 to 2050). In the model that aims to analyze climate change policy in the long run, technology improvement and new technology can play important roles. To capture these factors, we consider the following technology improvement and new technology. First, we assume total factor productivity (TFP) growth for every production sector. TFP here means the efficiency of the inputs of primary factors, and it is captured by a parameter in the production functions. In addition, we assume autonomous energy efficiency improvement (AEEI) for energy inputs in production and consumption. These technology improvements are assumed to be exogenous. Second, we assume that electricity is generated not only by conventional energy (fossil fuel, hydropower and nuclear energy) but also by 
renewable energy. Although the supply of electricity by renewable energy is limited at first due to its high cost, it increases gradually as the price of electricity rises.

Third, we consider carbon capture and storage (CCS) activity. CCS activity is modeled as an independent production activity that uses production factors and intermediate inputs. As electricity can be generated by the use of renewable energy, CCS activity is not supplied at first because it is not profitable. However, the increase in carbon prices caused by carbon regulation makes CCS activity profitable, and the amount of CCS will gradually increase. Due to the existence of CCS activity, we calculate net $\mathrm{CO}_{2}$ emissions as gross $\mathrm{CO}_{2}$ emissions minus CCS.

Although our model focuses on Japan, we need to consider international trade with other regions. To model international trade, we employ the small country assumption, where the terms of trade of Japan are kept constant. In addition, we use the so-called Armington assumption, which means that imported goods are imperfect substitutes of domestic goods. To incorporate the Armington assumption, we use the constant elasticity of substitution (CES) function to aggregate imported and domestic goods.

In the simulation, we analyze the regulation of $\mathrm{CO}_{2}$ emissions. To regulate $\mathrm{CO}_{2}$ emissions, we use a carbon tax. The carbon tax generates additional revenue for the government, and we consider the following two uses. First, we assume that carbon tax revenue is directly rebated to the representative household. Second, we assume that carbon tax revenue is used to reduce existing taxes such as the income tax, corporate tax and consumption tax. The latter case indicates environmental tax reform (the combination of a carbon tax and the reduction in existing taxes). We assume that the (net) $\mathrm{CO}_{2}$ emissions in Japan are reduced by $80 \%$ by 2050 , which is the actual reduction target of Japan. $\mathrm{CO}_{2}$ emissions are gradually reduced to achieve the target level in 2050 .

\subsection{Scenarios}

In this subsection, we explain the scenarios employed in the simulation. Table 1 lists the scenarios. The BAU scenario is a reference scenario where no (explicit) carbon regulation is executed. In the other three scenarios from LMP to COR, a carbon tax is adopted to regulate $\mathrm{CO}_{2}$ emissions. In scenario LMP, we assume that carbon tax revenue is rebated to the household in a lump-sum way. In the other two scenarios, carbon tax revenue is used to reduce the existing taxes. In scenario SSC, we reduce the social security contribution of the employer. Strictly speaking, the social security

Table 1 Simulation scenarios

\begin{tabular}{l|l}
\hline Scenario & Explanation \\
\hline BAU & Reference scenario (without carbon tax) \\
\hline LMP & Carbon tax + lump-sum rebate \\
\hline SSC & Carbon tax + social security contribution cut \\
\hline COR & Carbon tax + corporate tax cut \\
\hline
\end{tabular}


Table 2 Simulation results of a dynamic CGE

\begin{tabular}{l|l|l|l|l}
\hline & & LMP & SSC & COR \\
\hline 2030 & GDP & -0.59 & -0.10 & 0.38 \\
\hline & Income & -0.83 & -0.34 & 0.44 \\
\hline & Carbon tax revenue & 10,287 & 10,651 & 10,364 \\
\hline & Rebated revenue & 0 & 7,634 & 6,707 \\
\hline & GDP & -2.06 & -1.44 & -0.95 \\
\hline & Income & -2.93 & -2.25 & -1.51 \\
\hline & Carbon tax revenue & 14,055 & 14,403 & 14,499 \\
\hline & Rebated revenue & 0 & 8,509 & 7,480 \\
\hline
\end{tabular}

GDP, Income $\rightarrow \%$

Carbon tax revenue and rebated revenue $\rightarrow$ billion yen

contribution of the employer is not a tax. However, it is similar to a tax on labor because employers have to contribute to the social security of their employees. The reduction in the social security contribution will stimulate employment and the labor supply, thereby increasing production. The results of scenario SSC are presented in Sect. 4.

Scenario COR assumes that the carbon tax revenue is used to reduce the corporate tax. The corporate tax in this model is a tax on return on capital. ${ }^{2}$ Therefore, the reduction in the corporate tax stimulates investment (accumulation of capital stock), thereby increasing production. The results from scenario COR are discussed in Sect. 3.

\subsection{Simulation Results}

Although our simulation derives various quantitative economic impacts, we present only the results relevant for the analyses in later sections. Table 2 reports the simulation results. "GDP" and "Income" indicate the percentage change in the GDP and national income caused by the values (\%) used in scenario BAU in 2030 and 2050. "Carbon tax revenue" indicates carbon tax revenue (billion yen), and "Rebated revenue" (billion yen) indicates how much the existing taxes are reduced. In scenario LMP, carbon tax revenue is rebated directly to the household, and the value of the "rebated revenue" is zero. Carbon tax revenue is used to reduce the existing taxes in scenarios SSC and COR. The value of the "rebated revenue" is less than that of "carbon tax revenue" because carbon regulation decreases other tax revenue (revenue, for example, from the income tax, consumption tax and so on), and we cannot use all of the carbon tax for reducing the existing taxes.

\footnotetext{
${ }^{2}$ In the CGE analysis, "profit" is captured as payment toward capital. Thus, the corporate tax is understood as a tax on the return on capital.
} 
Let us examine the results. In scenario LMP, the carbon tax decreases the GDP and income in 2050 by $2.06 \%$ and $2.93 \%$, respectively. This is the pure impact of $\mathrm{CO}_{2}$ regulation, and this result indicates that an $80 \%$ reduction in $\mathrm{CO}_{2}$ has large negative macroeconomic impacts on the Japanese economy. The GDP and income also decrease in SSC. However, the size of the decrease is less than that in scenario LMP. This is because scenario SSC with the reduction in the social security contribution generates a RR effect that increases employment and the labor supply. This $\mathrm{RR}$ effect offsets some of the negative impacts of $\mathrm{CO}_{2}$ regulations, thus reducing the decrease in GDP and income.

Similarly, in scenario COR, the GDP and income decrease in 2050, and as in scenario SSC, the size of the decrease in the GDP and income is less than that in the previous simulation. However, $\mathrm{CO} 2$ regulation in scenario $\mathrm{COR}$ has positive impacts on the GDP and income in 2030; in other words, we have the strong double dividend effect in scenario COR in 2030. This is because the RR effect in scenario COR significantly stimulates investment and thereby increases the GDP and income.

Finally, let us see the value of the carbon tax. Carbon regulations generate carbon tax revenue of approximately 10 trillion yen in 2030 and 14 trillion yen in 2050. In scenarios SSC and COR, a part of this carbon tax revenue is used to reduce social security contributions and corporate taxes. These values are used in a later section.

In Sect. 3, we evaluate the impacts of RR on individual sectors in detail. For that analysis, we use other simulation results not shown in this section, for example, impacts on sectoral outputs and prices. Due to space limitations, we omit these results.

\section{Double Dividend Through Corporate Tax Reduction}

This section discusses the impact of the corporate tax reduction under the carbon tax reform examined in the previous section. We focus on the financial impacts on selected industries. The most common method for assessing the impact of carbon pricing on industry is employing economic simulation models to quantify the impact on each industrial sector. The information regarding the overall impact on each sector obtained through this method can be useful for planning measures such as tax exemptions.

However, carbon pricing has often been understood only as a short-term increase in the cost of energy and raw materials for firms (IGES 2016). This is also true even if the economic simulation models predict the possibility of some sectors having increased profits or a very small negative impact on profits. Individual firms are rarely aware that profits can increase as a result of a positive economic effect and the tax RR effect. These firms can understand the benefit of RR only after they see the simulation for each individual firm.

We analyze the financial impact of carbon pricing on individual firms by reflecting the effects of the carbon tax predicted by the economic simulation model in Sect. 2. In the analysis, we build on the results provided in Sect. 2. 


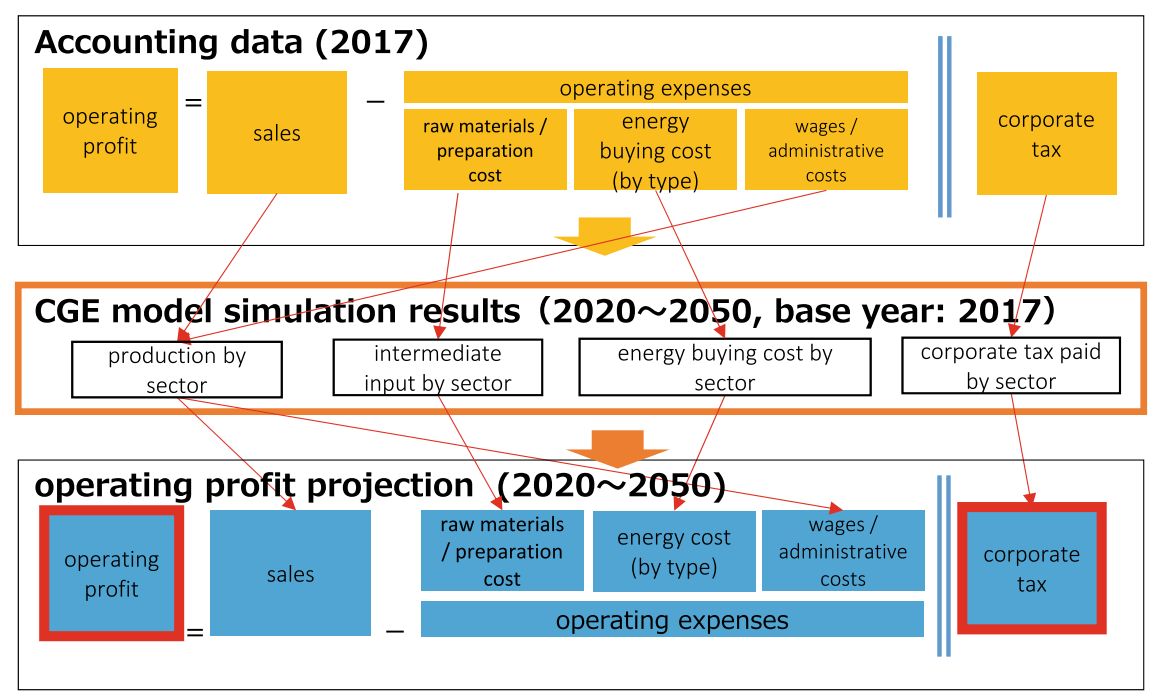

Fig. 1 Methodology used to assess the results of the economic simulation model on firm accounting

\subsection{Analysis Method}

\section{Analysis indicators and methodology}

This analysis assumes that the carbon tax proposed in Sect. 2 is employed and examines the financial impact on individual firms. To indicate financial performance, we employ operating profit (or operating loss) and the operating profit ratio. ${ }^{3}$

Figure 1 shows the methodology used to calculate the results of the economic simulation model (CGE model) that is described in Sect. 2 on firm accounting.

As shown in Fig. 1, first, data on the sales and operating expenses, which are the two factors to calculate the operating profit, were obtained from the financial disclosure reports of the firms targeted for the analysis. Data on the energy cost, which is a part of the operating expenses, and the consumption structure of each type of energy were obtained from the corporate social responsibility (CSR) reports of the targeted firms.

Next, for each sector, each component of the operating profit, i.e., the production amount, energy cost by energy type, and corporate tax cost, was calculated from 2020 to 2050 (in 10-year intervals) by applying the growth rate from 2017 calculated by

\footnotetext{
${ }^{3}$ Operating profit and the operating profit ratio are the financial indicators of the core business of the firm and affect its decision-making; they are not affected by financial factors unrelated to the core business, such as the corporate tax. Therefore, even if the collection of a carbon tax results in a reduction of the corporate tax, operating profit and the operating profit ratio would remain unchanged. To overcome this issue, this analysis includes in its calculations the corporate tax reduction in addition to the variation in operating profit. In this way, the analysis compares the impact of the corporate tax reduction when there is a decrease in operating profit.
} 
Table 3 Financial data of the firms targeted for analysis (2017) (Unit: million JPY)

\begin{tabular}{l|l|l|l|l|l|l}
\hline Sector & $\begin{array}{l}\text { Operating } \\
\text { profit ratio } \\
(\%)\end{array}$ & $\begin{array}{l}\text { Operating } \\
\text { profit }\end{array}$ & Sales & Energy cost & $\begin{array}{l}\text { Other } \\
\text { operational } \\
\text { costs }\end{array}$ & $\begin{array}{l}\text { Corporate } \\
\text { tax }\end{array}$ \\
\hline $\begin{array}{l}\text { Land } \\
\text { transport }\end{array}$ & 2.30 & 40,000 & 1540,000 & 30,000 & 1470,000 & 10,000 \\
\hline $\begin{array}{l}\text { Electric } \\
\text { power }\end{array}$ & 4.40 & 110,000 & $2,600,000$ & 710,000 & $1,770,000$ & 20,000 \\
\hline
\end{tabular}

Note regarding land transportation, operating costs apart from "Energy purchasing costs", such as vehicle depreciation costs, leasing costs, etc. are included in "Other operational costs"

the CGE model simulation in Sect. 2. We use data from 2017 as the reference year. For instance, the growth rate of the production in each sector was used to calculate the sales and the wages/administrative cost. The growth rate of the intermediate inputs, energy costs and the coporate tax paid in each sector were used to calculate the raw material cost, energy cost and corporate tax, respectively.

\section{Scenarios and the target sectors}

To analyze the effects of the carbon tax as well as the tax RR effect, the following two scenarios were analyzed. One is a scenario where a carbon tax is not introduced (BAU). Another is a scenario where a carbon tax is introduced, and tax revenue is used to reduce the corporate tax (COR).

Out of the 17 sectors that are included in the economic simulation models (CGE models) in Sect. 2, we target the land transportation sector and the electric power sector. These two sectors were chosen for this analysis for two reasons. First, the firms in these sectors focus on the activities in that sector and do not conduct business activities in other sectors. In this sense, they are highly homogeneous. Second, these two sectors could be directly affected by the carbon tax because they use a large amount of fossil fuel.

\section{Firms targeted for analysis}

We target one firm from each sector chosen for the analysis, as shown in Table 3. We selected firms that mainly focused on their own main sector and conducted few activities in other sectors. ${ }^{4}$

\footnotetext{
${ }^{4}$ For example, firms in the paper and pulp industry often are involved in business activities outside the paper and pulp industry. In this case, the analysis of the carbon tax burden becomes complex. We avoid those sectors.
} 


\subsection{Impacts of the Corporate Tax Reduction Under a Carbon Tax on the Selected Sectors}

To assess the effect of this corporate tax reduction on operating profit, a comparative analysis between the BAU and COR scenarios was carried out for the year 2050 focusing on the profits and losses resulting from the carbon tax (Figs. 2 and 3).

\section{Land transportation sector}

Figure 2 illustrates how profit changes due to the carbon tax and the corporate tax reduction for a firm in the land transportation sector. The increase in energy costs due to the carbon tax equals $38.6 \%$ of the operating profit in scenario BAU. However, the increase is neutralized by other profits, namely, increased profit from an increase in sales. Thus, the reduction in the operating cost is $29.4 \%$ before the corporate tax reduction.

In the COR scenario, however, the reduction in the corporate tax will financially help the firm financially by the amount of $10.9 \%$ of the profit. Consequently, the profit loss is reduced to $18.5 \%$. The corporate tax reduction significantly eases the economic burden.

\section{Electric power}

Figure 3 illustrates how profit changes due to the carbon tax and the corporate tax reduction for a firm in the electric power sector. The increase in energy costs due to the carbon tax equals $52.2 \%$ of the operating profit in scenario BAU. However, the

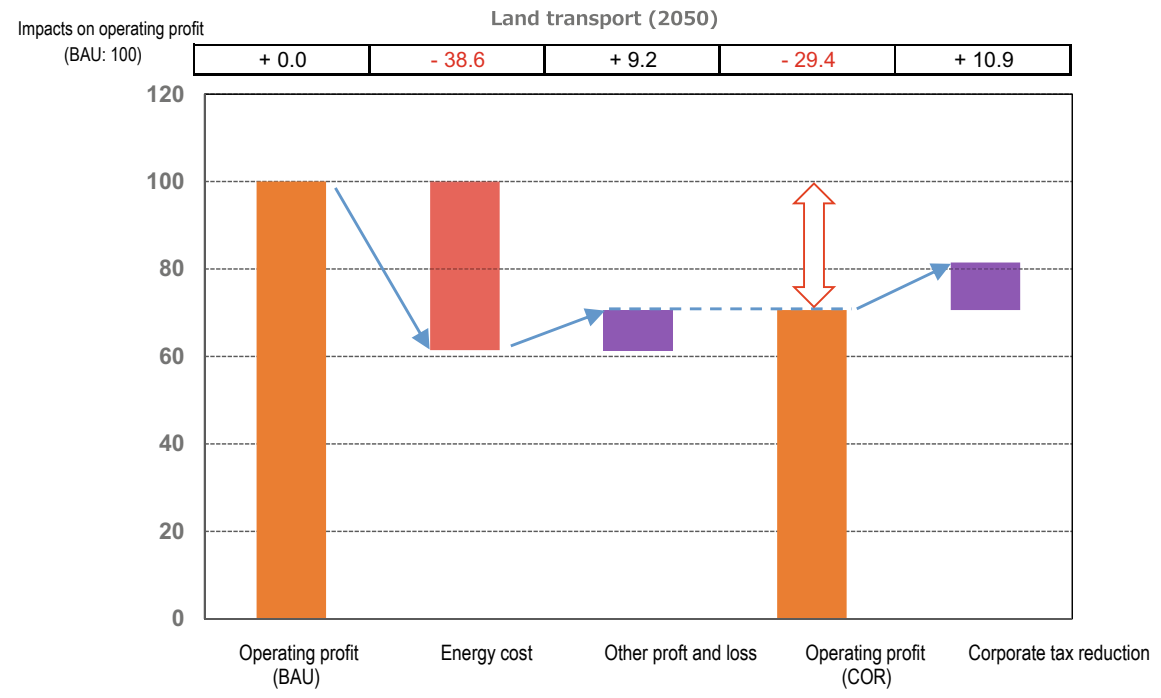

Fig. 2 Comparative analysis of operating profits in the BAU and COR scenarios (Land transport in 2050) 


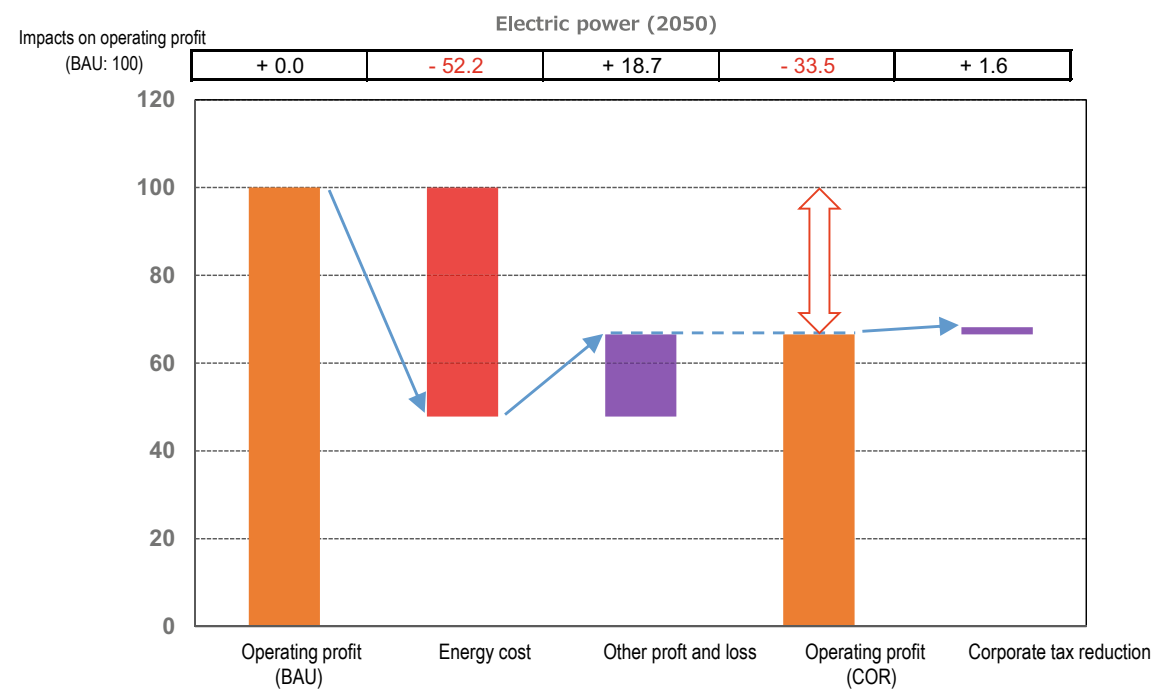

Fig. 3 Comparative analysis of the operating profits in the BAU and COR scenarios (electric power in 2050)

increase is neutralized by other profits, namely, increased profit from an increase in sales. Thus, the operating cost is reduced by $33.5 \%$ before the corporate tax reduction.

In the COR scenario, however, the reduction in the corporate tax will financially help the firm by the amount of $1.6 \%$ of the profit. Consequently, the profit loss is $31.9 \%$. The corporate tax reduction eases the economic burden only slightly in this case compared to the case of land transport.

\subsection{Discussion on the Corporate Tax Reduction}

Our analysis shows that the increase in energy costs is neutralized by the corporate tax reduction in the COR scenario to a certain degree, although the operating profit decreases as a result of the carbon tax. Thus, we confirm the benefits of the double dividend policy for industry stakeholders. By showing these results, we may be able to obtain more public support for carbon pricing from industry stakeholders.

We would like to note that the benefit of the corporate tax reduction depends on the size of the corporate tax on the operating profit. It is expected that the effect of the corporate tax reduction on profit will increase as the ratio of the corporate tax to operating profit increases. Moreover, the costs resulting from the carbon tax increase as the level of carbon intensity increases. When we consider these two factors together in the COR scenario, the net cost of the carbon tax would follow the patterns shown in Table 3. In fact, firms in some sectors, such as the service sector, may earn more "profit" when the effect of the tax reduction is larger than the costs. 
Table 4 Level of the net cost of carbon tax in the COR scenario

\begin{tabular}{|c|c|c|c|c|c|}
\hline \multirow{2}{*}{\multicolumn{2}{|c|}{$\begin{array}{l}\text { Net cost resulting from } \\
\text { carbon tax }\end{array}$}} & \multicolumn{3}{|c|}{ Carbon intensity } & \\
\hline & & Low & Medium & High & \\
\hline \multirow{3}{*}{$\begin{array}{l}\text { The ratio } \\
\text { of } \\
\text { corporate } \\
\text { tax per } \\
\text { operating }\end{array}$} & High & (Minus) & Low & Medium & \\
\hline & Medium & \multicolumn{2}{|c|}{ Land transport } & & Electric power \\
\hline & $\begin{array}{c}\text { Low } \\
\text { (- zero) }\end{array}$ & Low & Medium & High & \\
\hline
\end{tabular}

When we consider the carbon intensity and the ratio of corporate tax per operating profit of the targeted firms, the values in the land transport sector could be low and those in the electric power sector could be high in terms of the level of net cost of the carbon tax under the COR scenario (Table 4).

\section{Revenue Recycling to Households Through the Social Insurance System}

\subsection{Significance of Revenue Recycling to Households: Viewpoint of Labor Market Efficiency}

This section discusses the impacts of the RR of carbon tax through the social insurance system. There are two channels in which RR can stimulate economic activities by removing distortions in markets. First, RR can increase the labor demand of firms. RR through the social insurance system encourages firms by providing incentives to hire more employees. The financial resources of the social insurance system mainly consist of taxes and social insurance premiums. If the insured is an employee, there is an employer burden. In Japan, social insurance premiums are borne equally by workers and employers (50\% each) basically. For firms, the employer burden is only reflected as labor costs. firms are less willing to hire employees if they face a greater insurance burden. The presence of social insurance premiums has created inefficiencies in the labor market. Therefore, if government revenue from carbon pricing is used to reduce social insurance premiums, labor costs will decrease, and firms will have more incentives to hire employees. In other words, RR through the social insurance system increases the efficiency of the labor market.

Second, RR through the social insurance system can encourage households to increase their labor supply. Households supply labor and earn wages in the labor market. However, wages are different from disposable income. Households obtain disposable income when the government deducts taxes and social insurance premiums from wages. The determination of the household labor supply depends on disposable income. The burden of taxes and social insurance premiums basically 
increases as income increases. Therefore, to avoid the burden of social insurance premiums, employees often suppress their labor supply. Social insurance premiums work as a disincentive for the labor supply of households, creating labor market inefficiencies. If government revenue from carbon pricing is used to reduce social insurance premiums, disposable income will increase, and household labor supply will increase. In other words, the recycling of government revenue through the social insurance system increases the efficiency of the labor market.

\subsection{Revenue Recycling Through the National Pension System}

\section{Structure of the public pension system in Japan}

There are three ways we can recycle carbon tax revenue through the social insurance system: (1) the public pension system, (2) the public health insurance system, and (3) the long-term care insurance system. In this study, the public pension system is considered.

Japan's public pension system is a universal pension system. Figure 4 illustrates the basic structure of the national pension system in Japan. An employee joins the employee's pension insurance system and simultaneously becomes an insured person of the national pension system. In the national pension system, the person insured through the employee's pension is called a Category II insured person. The dependent spouse of a Category II insured person is a Category III insured person. If s/he is not a Category II or the Category III insured person, s/he will be a Category I insured person, basically a self-employed person, unemployed person, student, part-time worker, etc.

A person insured by the employee's pension bears an insurance premium in proportion to his or her wages. This premium includes the national pension premium. Similarly, a person insured by the employee's pension receives pension benefits in proportion to his or her wages. This pension benefit includes the benefit of the national pension (basic pension). The employee's pension premium is equally borne by the workers and employers (50\% each). However, Category I insured persons with only the national pension system basically bear a fixed premium ( $¥ 16,410$ in FY2019).

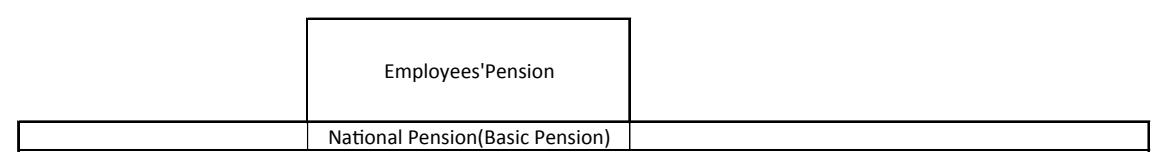

$\underbrace{\text { (self-employed persons,etc...) }}_{\text {Category I insured persons }} \underbrace{\text { (private and public workers) }}_{\text {Category II insured persons }} \underbrace{\text { (dependent spouse of the Category II insured persons) }}_{\text {Category III insured persons }}$

Fig. 4 Structure of the Public Pension System in Japan. Source Drawn by the Author 
Category III insured persons can benefit from the national pension (basic pension) without paying premiums. ${ }^{5}$

\section{Revenue recycling method in the public pension system}

In the discussion of RR through the public pension system, it is assumed that the insurance premium burden for the national pension system will be reduced. ${ }^{6}$ This is because the national pension system forms the basis of the universal pension system and can be widely recycled to the insurance of the public pension system. Based on the basic pension contribution structure, the government revenue from carbon pricing is recycled to the insured of the employee's pension system (for Category II insured persons) and Category I insured persons in the national pension system according to the number of insured persons. According to the basic pension contribution structure, the number of Category III insured persons is the number of insured persons under the employees' pension insurance system. For Category I insured persons, the insurance premium is reduced by dividing the government revenue by the number of insured persons covered by the national pension system. For Category II insured persons, the insurance premium will be reduced in consideration of the number of Category III insured persons. However, since the insurance premium burden is equally borne by workers and employers ( $50 \%$ each), the reduction in the insurance premium burden for Category II insured persons will be $50 \%$. In this way, the government revenue from carbon pricing is recycled to households in the form of reducing the insurance premium burden for the national pension system. For firms, the burden of social insurance premiums is also reduced.

The Japanese economy is facing a decreasing and aging population. Therefore, it is important to clarify the assumption regarding the structure of the population. We adopt a scenario based on government planning for the pension system. Specifically, in this analysis, we use the median estimate of the number of insured persons as shown in the fiscal verification published in 2019 by the Ministry of Health, Labor and Welfare. Fiscal verification is employed to examine the sustainability of the public pension system in several cases with respect to economic assumptions regarding factors such as the population and labor participation. The case used in the analysis is a case where labor participation progresses. The population is based on the median estimates published by the National Institute of Population and Social Security Research, where the sustainability of the public pension system as indicated in the 2004 pension reform will be maintained. The government should employ this economic assumption. Therefore, this case is used as a premise of the analysis here. A detailed discussion of the 2004 pension reform is beyond the scope of this book. The total amount of RR is 8.5 trillion yen in 2030 and 7.6 trillion yen in 2050 .

\footnotetext{
${ }^{5}$ This is called the problem of Category III insured persons. This problem can be divided into two parts. The first part concerns the fairness of the burden and benefits. The second part concerns a reduction in working hours to avoid the premium burden. Please see Kimoto (2016), which elaborates on this problem, for a detailed discussion.

${ }^{6}$ The benefit from revenue recycling is the reduction in the premium burden. However, if the premium is exempted, and the burden is less than the benefit from revenue recycling, the difference will be paid in cash.
} 
Table 5 Decrease of the Burden under Revenue Recycling through the National Pension System (yen)

\begin{tabular}{l|l|l|l}
\hline \multirow{2}{*}{ Year } & RR to category I & RR to category II & The revenue to employers (Trillion) \\
\cline { 2 - 4 } & $(1)$ & $(2)$ & $(3)$ \\
\hline 2030 & 137,346 & 78,710 & 3.4 \\
\hline 2050 & 159,070 & 90,187 & 3.1 \\
\hline
\end{tabular}

Source Authors' own calculation

\section{Simulation results}

The simulation results are shown in Table 5. Column (1) shows the decrease in the burden for a Category I insured person. Similarly, column (2) shows the decrease in the burden for a Category II insured person. Finally, column (3) exhibits the decrease of the payment for the employer sector. The employer sector refers to firms that employ Category II insured persons. ${ }^{7}$ All figures are shown in nominal amounts.

According to the simulation results, the payment for the national pension for Category I insured persons would decrease by $137,346(159,070)$ yen annually in 2030 (2050) if they are paying the premium fully without any exemptions. Similarly, column II shows that the payment of the premium for Category II insured persons would decrease by 78,710 (90,187) yen annually in 2030 (2050). Column (3) shows the decrease in the payment for the employers. The burden for the employer would decrease by 3.4 (3.1) trillion yen in 2030 (2050).

\section{Discussion}

First, Table 5 shows that the amount of RR to a Category I insured person is greater than that to a Category II insured person. Category I insured persons are better off than those in Category II. The reason for this difference is that, for a Category II insured person, the amount of the RR will be split with the employer. That is, some portion of the revenue is given to employers, while employees would receive only a part of the revenue.

The total amount of the recycled revenue will be lower in 2050 than in 2030. However, the amount of recycled revenue to the insured will be larger in 2050 than in 2030 for both (1) and (2). This is because the number of insured persons decreases simply due to the declining birthrate, and the amount per person increases. However, the amount of RR to the employer is not affected by the declining birthrate, so the amount of RR is higher in 2030 than in 2050.

Let us consider the following three types of households based on the simulation results for 2030: (1) self-employed married households (family type I), (2) married households of firm employees (family type II), and (3) married households of firm employees and full-time housewives (family type III). The self-employed married households (family type I) consist of two Category I insured persons, so the amount of RR is 274,692 yen, doubling the benefit of Category I insured persons. For the

\footnotetext{
${ }^{7}$ Therefore, this sector includes not only firms but also the government sector.
} 
Table 6 Net Benefit of Revenue Recycling through the National Pension System (Yen)

\begin{tabular}{l|l|l|l}
\hline & $\begin{array}{l}\text { Self-employed married } \\
\text { households }\end{array}$ & $\begin{array}{l}\text { Married households of } \\
\text { firm employees }\end{array}$ & $\begin{array}{l}\text { Married households of } \\
\text { firm employee and } \\
\text { full-time housewife }\end{array}$ \\
\cline { 2 - 4 } & Family type I & Family type II & Family type III \\
\hline Benefit & 274,692 & 157,420 & 78,710 \\
\hline Net benefit & 120,239 & 2967 & $-75,743$ \\
\hline
\end{tabular}

Source Authors' own calculation

married households of firm employees (family type II), the amount of RR is 157,420 yen. Here, we also assume that both the wife and husband work full-time. The married households of firm employees and full-time housewives (family type III) are composed of a Category II insured person and a Category III insured person, so the amount of RR is only 78,710 yen. As a result, households with a Category I insured person receive a generous benefit. The results of this simulation for all three types of households are illustrated in the first row of Table 6 .

Meanwhile, households face an increase in expenditures if firms pass all the costs of the carbon tax to their customers. Using IO table analysis, Kameoka and Arimura (2019) examined the impacts of the cost increase from a carbon tax on the Japanese economy. They simulated a carbon tax of 2905 yen per ton of $\mathrm{CO}_{2}$ and found that the expenditures of a typical household consisting of two family members or more is 28,968 yen annually. In the CGE analysis, the level of carbon tax in 2030 is 15,489 yen. Given the linear nature of the IO analysis, we can infer that the expenditures of a typical household increases by 154,453 yen. Using this estimate, we can compute the net benefit of RR under carbon pricing. The net benefit for each family type by subtracting this increase in expenditures from the benefit of RR is shown as the "net benefit" in the second row of Table 6.

What will be the outcome of RR be for each family type? Family type I is better off with a carbon tax if RR is adopted for the national pension system. Thus, family type II is not worse off even under carbon pricing. We expect that the government can gain public support for the carbon tax from these types of households if the revenue is recycled in this way. In contrast, the burden for family type III will increase by 75,473 yen annually.

RR can have an impact on the labor supply. The RR method described above provides incentives for the labor supply of Category III insured persons. Category III insured persons can receive benefits from the national pension (basic pension) without incurring premiums. Therefore, the labor supply is adjusted such that Category III insured persons will remain in their position to avoid the premium burden. In this situation, what will happen if RR through the national pension system is implemented? If Category III insured persons remain in their position, they will not benefit from RR. Therefore, there is a possibility to shift to Category II insured persons without adjusting the labor supply to benefit from RR. Of course, if Category III insured persons shift to Category II insured persons, insurance premiums will be 
incurred, so even if RR is considered, disposable income will not necessarily increase. However, if Category III insured persons become Category II insured persons, they will obtain pension benefits proportional to their wages. This pension benefit is greater than that of the basic pension. Considering this pension benefits when they become the elder, the workers determine the labor supply. If RR through the national pension system is implemented, the labor supply will be encouraged, and thus, they could receive this pension benefits and also benefit from RR. Thus, RR through the national pension system will promote the labor supply.

The RR in this section is consistent with the current government policy regarding social security reform. The setting of RR is intended for "insured persons" of the national pension. Pensioners (basically the elderly) are not eligible for this benefit. The RR considered in this study benefits the working generation. Until now, social security in Japan has been concentrated on the elderly, but in recent years, the government has started to pay attention to younger generations. Thus, social security for the working generation has been emphasized. The RR envisaged in this study is targeted at the working generation and is consistent with government policy regarding social security reform.

\section{Conclusion}

In this chapter, we examined the impacts of environmental tax reform on households and firms in selected sectors with the aim of reducing GHG emissions by $80 \%$ in 2050. Specifically, based on the simulation results of a dynamic CGE model, we investigated the impacts of two types of RR. One is corporate tax reduction for firms, and the other is a reduction in social security payments.

To assess the corporate tax reduction, we examined two sectors: the land transportation and the electric power sectors. We found that even when employing a high carbon price to achieve the national emission reduction target, the cost increase from the carbon tax can be offset to a certain degree with RR through a corporate tax reduction.

For the case of a reduction in social security payments, we found that some households are better off if the government uses the revenue from the carbon tax to reduce social security payments. Thus, RR from a carbon tax is an attractive option for some firms and households.

In many cases, the introduction of carbon pricing faces opposition from various stakeholders. However, the simulations conducted in this chapter illustrate that, at the individual firm level or at the household level, some stakeholders that are better off with RR. Therefore, providing information on these micro data analyses can increase support for carbon pricing.

We should mention some caution should be taken when interpreting these results. Regarding the corporate tax reduction, we should pay attention to the following. First, we should scrutinize the benefit for firms more carefully. That is, it is necessary to further divide the operating costs of the target firms to increase the accuracy 
of the future projection of operating costs. However, published data on the land transportation sector and electric power sector, which were targeted for this analysis, are limited at this time. As a result, almost all operating costs apart from energy costs had to be included in "other operating costs" and managed in the same way, and the accuracy of the projections may have decreased. In the future, it would be desirable to use detailed data on operating costs.

In addition, regarding the effect of the corporate tax reduction on profits, as noted in an article published in a Japanese newspaper (Shimbun NK 2019), ${ }^{8}$ the tax burden rate (the ratio of taxes paid to profit) varies largely between firms due to an adjustment in the tax standards (from under $10 \%$ to approximately $40 \%$ ), and this may also be true for the corporate tax. This variation can result in a large difference between the predicted and real effects of the corporate tax reduction. Therefore, when implementing corporate tax reduction measures, it will be necessary to be careful and use more detailed data.

Regarding the effect of the reduction in taxes on the labor supply, we should examine other channels of RR. Specifically, in addition to the national pension system, Japan has a public health insurance system and a long-term care insurance system. The government can recycle carbon tax revenue using these systems as well. This can be a topic for further study, as the discussion on RR through these systems will also be important.

\section{References}

Agnolucci P (2009) The effect of the German and British environmental taxation reforms: a simple assessment. Energy Policy 37(8):3043-3051

Beuermann C, Santarius T (2006) Ecological tax reform in Germany: handling two hot potatoes at the same time. Energy Policy 34(8):917-929

Carattini, S, Carvalho M, Fankhauser S (2017) How to make carbon taxes more acceptable. Grantham Research Institute on Climate Change and the Environment, and Centre for Climate Change Economics and Policy, London School of Economics and Political Science, London

Freire-González J (2017) Environmental taxation and the double dividend hypothesis in CGE modelling literature: A critical review. J Policy Model 40(1):194-223. https://doi.org/10.1016/j. jpolmod.2017.11.002

Goulder LH (1995) Environmental taxation and the 'double dividend': a reader's guide. Int Tax Publ Financ 2:157-183

IEA (2018) World energy outlook 2019, IEA, Paris https://www.iea.org/reports/world-energy-out look-2018

IGES (2016) Effectiveness and economic efficiency of carbon tax as an economic instrument to achieve substantial GHG emission reduction by 2050. Policy Stud Environ Econ, Ministry Environ (in Japanese)

Jorgenson DW, Goettle RJ, Ho MS, Wilcoxen PJ (2013) Double dividend: environmental taxes and fiscal reform in the United States. MIT Press, Cambridge, MA

Kameoka R, Arimura TH (2019) The impact of carbon tax \& feed-in tariff on the industry \& household expenditure-an input-output analysis-. Environ Sci 32(4):103-112 (in Japanese)

${ }^{8}$ Kigyo, Baratsuku Zei Futan ("Varying tax burdens for firms", published on Nhon Keizai Shinbun, 24 August 2019, morning newspaper, page 2). 
Kimoto K (2016) The problem of the Category-3 insured persons and policy-making for the expansion of the Employee's Pension Scheme. Nihon Univ Econ Rev 86(2/3):145-156 (in Japanese)

Lee S, Pollitt H, Park SJ (eds) (2015) Low-carbon, sustainable future in East Asia: Improving energy systems, taxation and policy cooperation. Routledge Studies in the Modern World Economy

MIC (2016) 2011 input-output tables for Japan. Ministry of Internal Affairs and Communications Japan

Nansai K, Kawasima K, Morimoto T (2018) The development of 3EID based on 2011 input-output table. In: The 13th Meeting of the Institute of Life Cycle Assessment, Japan

Pereira AM, Pereira RM, Rodrigues PG (2016) A new carbon tax in Portugal: a missed opportunity to achieve the triple dividend? Energy Policy 93:110-118. https://doi.org/10.1016/j.enpol.2016. 03.002

Saveyn B, Van Regemorter D, Ciscar JC (2011) Economic analysis of the climate pledges of the Copenhagen accord for the EU and other major countries. Energy Econ 33:S34-S40. https://doi. org/10.1016/j.eneco.2011.07.024

Shimbun NK (2019) Varying tax burdens for firms. (in Japanese): 2. Print

Takeda S (2007) The double dividend from carbon regulations in Japan. J Jpn Int Econ 21:336-364. https://doi.org/10.1016/j.jjie.2006.01.002

Takeda S, Arimura TH (2020) A computable general equilibrium analysis of environmental tax reform in Japan. Waseda RIEEM Discussion Paper No. 2002

Carbone J, Morgenstern RD, Williams RC, III, Burtraw D (2013) Deficit reduction and carbon taxes: Budgetary, economic, and distributional impacts. Resour Future

Yamazaki A (2017) Jobs and climate policy: evidence from British Columbia's revenue-neutral carbon tax. J Environ Econ Manage 83:197-216

Kenji Asakawa is a policy researcher of the Institute for Global Environmental Strategies, a semigovernmental think-tank for national and local policy on global environemnt. His research focuses on policy design of carbon pricing, such as the mitigation measures of the pricing impacts on carbon intensive companies, through a level playing field by minimizing the potential legal risks due to reverse discrimination against the mitigation measures. He obtained his Juris Doctor from Omiya Law School and passed the National Bar Examination.

Kouichi Kimoto is a Junior Researcher (an assistant professor) at Research Institute for Environmental Economics and Management, Waseda University. He received a PhD in Economics from Waseda University in 2019.

Shiro Takeda is a professor of Faculty of Economics at Kyoto Sangyo University and a member of the Research Institute for Environment Economics and Management at Waseda University. His research focuses on climate change policies in Japan and computable general equilibrium analysis. He holds his Ph.D. in Economics from Hitotsubashi University. In 2010, he is awarded Young Achievement Award from Society for Environmental Economics and Policy Studies in Japan.

Toshi H. Arimura is a Professor of Political Science and Economics and Director of the Research Institute for Environment Economics and Management at Waseda University in Tokyo. Prior to joining Waseda, he was a Professor at Sophia University in Tokyo and was a visiting scholar with George Mason University and Resources for the Future as a recipient of the Abe Fellowship. His research interests include climate change, energy policies, air pollution regulations and voluntary environmental actions. He has published his research in academic journals such as Journal Environmental Economics and Management, Journal of Association of Environmental and Resources Economics, Environmental and Resource Economics, Ecological Economics or Energy Policy. He is a coauthor of An Evaluation of Japanese Environmental Regulation: A Quantitative Approach 
from Environmental Economics (Springer 2015). Dr. Arimura holds a Ph.D. in economics from the University of Minnesota, an MSc in environmental sciences from the University of Tsukuba and a BA in history of science from the University of Tokyo. He has served on a number of Japanese government committees on environmental issues including the committees on carbon pricing (2018) and emission trading scheme (2010) of the environmental council under Ministry of the Environment. He is also a member of the Tokyo Metropolitan environmental council. He has served on advisory committees of local governments for emission trading schemes of Tokyo and Saitama. He has also been on editorial boards of academic journals such as Review of Environmental Economics and Policy, Agricultural and Resource Economics Review, Economics of Energy and Environmental Policy or Environmental Economics and Policy Studies. Since 2018, Waseda University has choses him as one of 10 next generation core researchers. He is a recipient of SEEPS Outstanding Publication Award from Society for Environmental Economics and Policy Studies (Japanese Association of Environmental Economics and Policy) and the academic award from Society of Environmental Science, Japan.

Open Access This chapter is licensed under the terms of the Creative Commons Attribution 4.0 International License (http://creativecommons.org/licenses/by/4.0/), which permits use, sharing, adaptation, distribution and reproduction in any medium or format, as long as you give appropriate credit to the original author(s) and the source, provide a link to the Creative Commons license and indicate if changes were made.

The images or other third party material in this chapter are included in the chapter's Creative Commons license, unless indicated otherwise in a credit line to the material. If material is not included in the chapter's Creative Commons license and your intended use is not permitted by statutory regulation or exceeds the permitted use, you will need to obtain permission directly from the copyright holder.

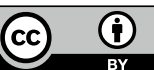

